\title{
Distribution of Thaliacea in SW Taiwan coastal water in 1997, with special reference to Doliolum denticulatum, Thalia democratica and T. orientalis
}

\author{
Kwee Siong Tew ${ }^{1,2}$, Wen-Tseng Lo ${ }^{1, *}$ \\ ${ }^{1}$ National Sun Yat-sen University, Institute of Marine Resources, Kaohsiung, 804, Taiwan, ROC \\ ${ }^{2}$ Present address: National Museum of Marine Biology and Aquarium, Pintung, 944, Taiwan, ROC
}

\begin{abstract}
Diel vertical migration of Thaliacea was monitored during different seasonal cruises in 1997 in the southwestern waters of Taiwan using samples collected by multiple plankton sampling nets and a $1 \mathrm{~m}$ plankton net. Overall, Doliolum denticulatum, Thalia democratica and T. orientalis were the 3 most dominant species in all seasons, and contributed $\geq 93 \%$ of the numerical total of Thaliacea. These species exhibited about a 2 times higher abundance at night than during the day, if all the data were integrated. In the seasonal multiple net samples, $D$. denticulatum and $T$. democratica exhibited an alternation between sexual and asexual reproduction between different sampling seasons, while aggregate zooids of $T$. orientalis, when compared with solitary zooids, dominated in all seasons and apparently increased from July to December. Different stages of these dominant species had different preferences for water depth in different seasons, suggesting that the vertical distribution of these species might be related to reproduction or food. The abundances of different stages of these thaliaceans were correlated with temperature and salinity. The time-series samples of surface water showed that species richness and abundance of these species varied seasonally, but was always greater at night than during the day.
\end{abstract}

KEY WORDS: Diel vertical migration · DVM · Thaliacea $\cdot$ Season · Taiwan $\cdot$ Western Pacific

\section{INTRODUCTION}

Pelagic tunicates are widely but often patchily distributed in the world's oceans (Thompson 1948, Deibel 1998). Some thaliaceans are found in dense populations at high latitudes (Bathmann 1988, Huntley et al. 1989), or in productive shelf and coastal waters (Wiebe et al. 1979, Zeldis et al. 1995), particularly during the spring phytoplankton bloom (Gorsky et al. 1991, Ménard et al. 1994, 1997). Some thaliaceans are known to perform extensive diel vertical migration (DVM); for instance, Salpa aspera migrates over $800 \mathrm{~m}$ in the slope water of the western North Atlantic (Wiebe et al. 1979), while Pyrosoma atlanticum migrates from 90 to $760 \mathrm{~m}$ with different colony sizes in the Ligurian
Sea (Andersen \& Sardou 1994). Purcell \& Madin (1991), however, mentioned that Cyclosalpa bakeri has a migration distance of only 60 feet in the subarctic, and Gibbons (1997) found Thalia democratica with little or no DVM in the Agulhas Bank, South Africa. Madin et al. (1996) reported that different species seemed to have different DVM patterns. Some hypotheses proposed that DVM serves to reduce visual predation (Pearre 1973, Ohman et al. 1983), to minimize photodamage (Haney 1988), to optimize feeding on algae (Enright 1977), to reduce metabolic costs (Wiebe et al. 1979), or to increase fecundity (Purcell \& Madin 1991).

There have been only a few studies of Thaliacea in the western Pacific (Deibel 1998). Chen et al. (1994) re- 
ported 8 unnamed species from their seasonal samplings in the waters around the Nansha (Spratly) Islands in the South China Sea. He et al. (1988) studied zooplankton in the coastal upwelling area of Zhejiang, China, and found that up to $16 \%$ of the total wet weight biomass of tunicates, primarily Thalia democratica, Doliolum denticulatum and Dolioletta gegenbauri, was composed of plankton. They are distributed unevenly, increase clearly in the frontal areas, and are negatively correlated with the abundance of copepods and euphausiids. Tsuda \& Nemoto (1992) reported 5 species of pelagic salps; T. democratica, Salpa fusiformis, Traustedtia multitentaculata, Cyclosalpa bakeri and Ritteriella reteacta accounted for $47 \%$ of the wet weight of zooplankton in the upper $200 \mathrm{~m}$ of a Kuroshio warm-core ring in summer 1987. They found that all salps appeared mainly in the surface mixed layer $(0$ to $20 \mathrm{~m})$, with the exception of $S$. fusiformis, which was most abundant from 50 to $75 \mathrm{~m}$. Fu et al. (1995) found only 1 thaliacean species, Cyclosalpa pinnata, with an abundance $<1$ ind. $\mathrm{m}^{-3}$ in zooplankton samples collected from the Pearl River estuary, southern China between June 1991 and March 1992. Among these studies, 2 were carried out in coastal areas (He et al. 1988, Fu et al. 1995), while others were concerned with salps in the open ocean or over continental slope. Relatively few of these studies discussed the DVM of salps and even fewer studies have dealt with different life stages of the same species.

The waters of southwestern Taiwan are a typical subtropical area, with different water masses and monsoons alternating seasonally. During the southwest monsoon season from late spring (May) to early autumn (September), warm and wet winds usually blow from the ocean to the land and cause higher precipitation (>100 $\mathrm{mm} \mathrm{mo}^{-1}$ ). The warmer and fresher South China Sea surface waters also flow northeastward, synchronizing with the southwest monsoon, intruding into the southern Taiwan Strait and dominating in this region. At the end of autumn (November) in the beginning of the northeast monsoon, the Kuroshio Current, a warm and highly saline North Pacific current, which originates from the North Equatorial Current east of the Philippines, moves closer towards the east coast of Taiwan and its branches pass through the Luzon Strait and intrude into the northern South China Sea and the waters off southwestern Taiwan (Wang \& Chern 1987, Shaw 1992). This results in a specific water layer between depths of 200 and $300 \mathrm{~m}$ in this area with an unusually high salinity and poor nutrients (Li et al. 1997, Xu \& Su 1997). However, the northeast monsoon, obstructed by the central mountain range of Taiwan, is generally cool and dry when blowing over the study area and normally makes the mean monthly rainfall $<50 \mathrm{~mm}$. The alternations of hydrological and climatic conditions in this region may, therefore, greatly influence the distribution patterns and succession of plankton communities as well as the ecosystems on a seasonal scale.

The area under study in this paper has been the subject of many oceanographic studies, both physical (Wang \& Chern 1987, Shaw 1989, Hung \& Shy 1995, Tseng 2002) and biological (Fong et al. 1990, Soong \& Chen 1991, Mok \& Kuo 2001), including zooplankton studies (Lo et al. 2001, 2004, Hwang \& Lo 2002), but no attention has been paid to pelagic tunicates. We initiated a project to observe such tunicates, which may play an important role in the ecosystem, with the objective of understanding the seasonal variation in species compositions and life stages of Thaliacea in the study area, and to elucidate the relationship between their patterns of vertical migration and hydrographical conditions.

\section{MATERIALS AND METHODS}

The sampling station (TS) was located at the Kaoping Trench, about $15 \mathrm{n}$ miles from the mainland and $8 \mathrm{n}$ miles northwest of Liuchiu Island, with a depth of about $500 \mathrm{~m}$ (Fig. 1). Zooplankton samples were collected both during the day (11:00 to $14: 00 \mathrm{~h}$ ) and at night (23:00 to 02:00 h) during the cruises of RV 'Ocean Researcher III' on May 2-3, July 7-8, October 17-18 and December 27-28, 1997. We used a rectangular opening and closing multiple plankton sampler (Hydro-Bios), with a mouth area of $0.25 \mathrm{~m}^{2}$, a mesh size of $330 \mu \mathrm{m}$, and a Hydro-Bios flowmeter fixed at the centre of the mouth of each net. The sampler was first lowered to $200 \mathrm{~m}$ and opened the first net at this depth. It was towed horizontally at a cruising speed of about 2 knots for about $30 \mathrm{~min}$. Then, the sampler was quickly pulled up to $150 \mathrm{~m}$ to open the second net and close the first net simultaneously, and towed as for the first net. This process was repeated at depths of 100, 50 and 0 to $1 \mathrm{~m}$. In total, 38 samples were collected, with the loss of 2 samples due to a mechanical problem with the second net $(150 \mathrm{~m})$ in May. Hydrological variables such as water temperature, salinity and fluorescence were measured with CTD probes (SeaBird Electronics) immediately before the plankton tow. The values of fluorescence were modified to the chlorophyll a concentrations ( $\mathrm{mg} \mathrm{l}^{-1}$ ) according to the results of concurrent water samplings.

Time-series of bi-hourly samples were taken at the same station (TS), over a $24 \mathrm{~h}$ period on March 14-15 and October 26-27, 1997. A $1 \mathrm{~m}$ net (1 m diameter opening, $4.5 \mathrm{~m}$ long, with a $330 \mu \mathrm{m}$ mesh size) with a Hydro-Bios flowmeter was towed horizontally near surface water (1 to $5 \mathrm{~m}$ ) with a cruising speed of about 


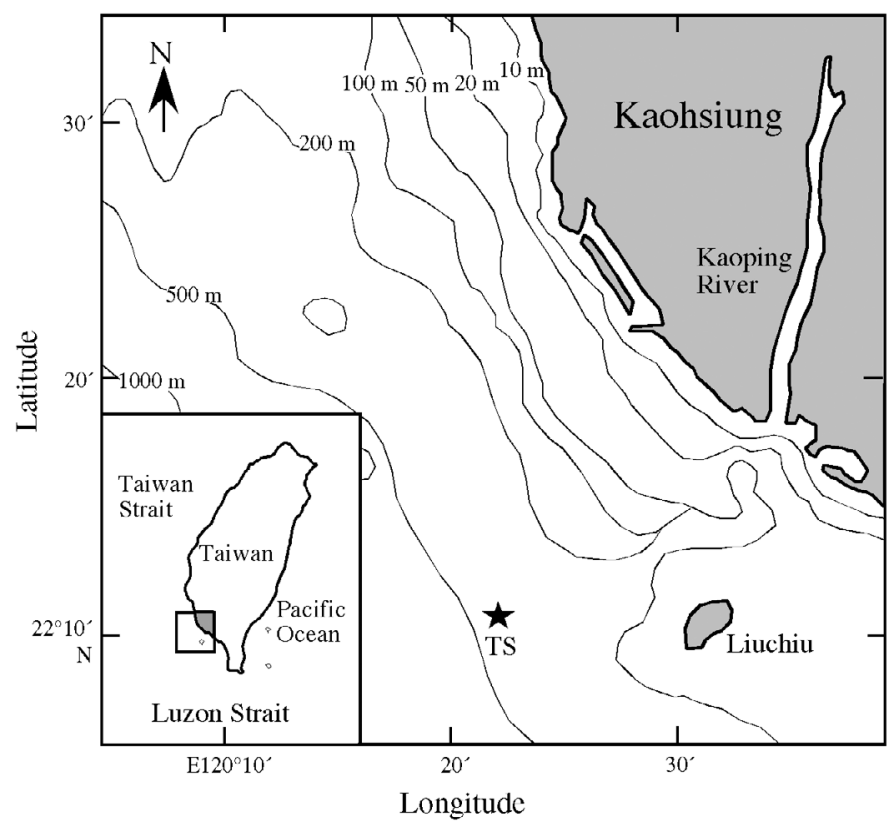

Fig. 1. The sampling station (TS) in the waters southwest of Taiwan

2 knots for $10 \mathrm{~min}$. After collection, all plankton samples were immediately preserved on board in $5 \%$ borax-buffered formalin in seawater. Identification and enumeration of specimens were performed in the laboratory under a dissecting microscope (Askania model GSZ 2) and, when necessary, under a light microscope (Olympus model BX50F-3). Doliolids were identified to species and 3 life stages: gonozooids, phorozooids and oozooids (nurse stage, the older phase of oozooids, was included in oozooids), and salps were identified to species and solitary and aggregate stages. The species identification was based on Thompson (1948), Yount (1954), Chihara \& Murano (1997) and Godeaux (1998).

The sampling data, including the filtered water volume, subsample size and number of thaliaceans counted in each sample, are listed in Table 1 . The filtered water volume varied from 71 to $671 \mathrm{~m}^{3}$ due to the direction of tow along or against the ocean currents and 3 to 449 thaliacean specimens were counted in each sample. Data of numerical abundance were standardized to ind. $\mathrm{m}^{-3}$ (except ind. per $10^{3} \mathrm{~m}^{3}$ in Table 2) before analysis. The weighted mean depths (WMD) (Roe et al. 1984) were calculated to show the preferred depths of different generations of the 3 most dominant species and to evaluate the distance they migrated between day and night. The equation of computation was:

$$
\mathrm{WMD}=\Sigma\left(n_{i} \times z_{i}\right) / \Sigma n_{i}
$$

where $n_{i}$ was abundance (ind. $\mathrm{m}^{-3}$ ) of species at depth $z_{i}$.
Forward stepwise regression and partial correlation were used to evaluate the relationships between the abundance of different generations of the 3 most dominant thaliacean species and the hydrological variables. To compare the thaliacean abundance during different diel periods, a data matrix of time versus species abundance was built. A Student's $t$-test was used to examine the significance of differences in the total abundance and also of the 3 most dominant thaliacean species between day (07:00 to 17:00 h) and night (19:00 to $05: 00 \mathrm{~h})$.

\section{RESULTS}

\section{Hydrographic conditions}

Vertical profiles of temperature, salinity and fluorescence at the sampling site are shown in Fig. 2. Surface temperature varied slightly among seasons, from $26.0^{\circ} \mathrm{C}$ in December to $28.8^{\circ} \mathrm{C}$ in July. The depth of the mixed layer was about $70 \mathrm{~m}$ in October and December, and about $20 \mathrm{~m}$ in July. No clear thermal stratification was present in May. Salinity in surface water ranged from 33.9 to $34.6 \%$ o during the study period, except in July when it was $32.7 \%$. In October, there was an unusual decline in salinity at a depth of $70 \mathrm{~m}$, coupled with a sudden peak of chlorophyll $a$ $\left(0.2 \mu \mathrm{g} \mathrm{l}^{-1}\right)$ and the beginning of a thermocline. The chlorophyll a concentration was generally low, except for 1 high value $\left(0.57 \mu \mathrm{g} \mathrm{l}^{-1}\right)$ found near the surface zone in July.

\section{Day and night vertical distribution}

There were 16 thaliacean species (14 species of salps and 2 species of doliolids) found in the multiple net collections (Table 2). Thalia democratica and T. orientalis were the most dominant salp species, while the majority of the doliolids were Doliolum denticulatum. These 3 dominant species were present in all samples, and contributed to $93 \%$ of the numerical total of Thaliacea. Seasonal changes in numerical abundance and species number of Thaliacea were notable, with a peak value, both in numerical abundance and species richness, in October and least abundance in May. Lowest species richness was found in July (Fig. 3). Abundance of total Thaliacea and the 3 dominant species at night was about 2 times as high as during the day when all the data were integrated (Table 2). No apparent difference was observed in species richness between day and night in all sampling seasons, with the exception of October, which showed higher species richness at night (Fig. 3). 
Table 1. Sampling data for the multiple plankton net and the $1 \mathrm{~m}$ net. FWV: filtered water volume; SS: subsample; AC: no. of animals counted in the subsample; N, D: night and day; -: no data

\begin{tabular}{|c|c|c|c|c|c|c|c|c|c|}
\hline Month/time & Depth (m) & $\mathrm{FWV}\left(\mathrm{m}^{3}\right)$ & SS & $\mathrm{AC}$ & Month/time & Depth (m) & $\mathrm{FWV}\left(\mathrm{m}^{3}\right)$ & SS & $\mathrm{AC}$ \\
\hline \multicolumn{5}{|c|}{ Multiple plankton net } & Dec/D & 100 & 297 & 1 & 292 \\
\hline May/D & 1 & 541 & $1 / 4$ & 299 & Dec/D & 150 & 280 & 1 & 14 \\
\hline May/D & 50 & 671 & $1 / 4$ & 227 & Dec/D & 200 & 106 & 1 & 3 \\
\hline May/D & 100 & 497 & $1 / 2$ & 103 & Dec/N & 1 & 96 & $1 / 2$ & 133 \\
\hline May/D & 150 & - & - & - & Dec/N & 50 & 187 & $1 / 4$ & 299 \\
\hline May/D & 200 & 289 & 1 & 8 & Dec/N & 100 & 238 & $1 / 2$ & 83 \\
\hline May/N & 1 & 276 & $1 / 4$ & 35 & Dec/N & 150 & 262 & 1 & 34 \\
\hline May/N & 50 & 488 & $1 / 4$ & 64 & $\mathrm{Dec} / \mathrm{N}$ & 200 & 174 & 1 & 11 \\
\hline May/N & 100 & 438 & $1 / 2$ & 4 & $1 \mathrm{~m}$ net & & & & \\
\hline May/N & 150 & - & - & - & Mar/17 & 1 to 5 & 329 & $1 / 2$ & 48 \\
\hline May/N & 200 & 494 & $1 / 2$ & 4 & Mar/19 & 1 to 5 & 141 & $1 / 2$ & 44 \\
\hline $\mathrm{Jul} / \mathrm{D}$ & 1 & 244 & $1 / 2$ & 238 & Mar/21 & 1 to 5 & 71 & $1 / 2$ & 94 \\
\hline $\mathrm{Jul} / \mathrm{D}$ & 50 & 208 & $1 / 2$ & 34 & Mar/23 & 1 to 5 & 126 & $1 / 4$ & 220 \\
\hline $\mathrm{Jul} / \mathrm{D}$ & 100 & 225 & $1 / 2$ & 59 & Mar/01 & 1 to 5 & 125 & $1 / 4$ & 128 \\
\hline $\mathrm{Jul} / \mathrm{D}$ & 150 & 146 & 1 & 26 & Mar/03 & 1 to 5 & 160 & $1 / 4$ & 136 \\
\hline $\mathrm{Jul} / \mathrm{D}$ & 200 & 160 & 1 & 16 & Mar/05 & 1 to 5 & 310 & $1 / 4$ & 188 \\
\hline $\mathrm{Jul} / \mathrm{N}$ & 1 & 120 & $1 / 2$ & 224 & Mar/07 & 1 to 5 & 214 & $1 / 4$ & 127 \\
\hline $\mathrm{Jul} / \mathrm{N}$ & 50 & 138 & $1 / 2$ & 58 & Mar/09 & 1 to 5 & 240 & $1 / 2$ & 167 \\
\hline $\mathrm{Jul} / \mathrm{N}$ & 100 & 168 & 1 & 48 & Mar/11 & 1 to 5 & 278 & $1 / 2$ & 105 \\
\hline Jul/N & 150 & 114 & 1 & 17 & Mar/13 & 1 to 5 & 86 & $1 / 4$ & 53 \\
\hline $\mathrm{Jul} / \mathrm{N}$ & 200 & 202 & 1 & 18 & Mar/15 & 1 to 5 & 199 & $1 / 2$ & 36 \\
\hline Oct/D & 1 & 324 & $1 / 4$ & 123 & Oct/17 & 1 to 5 & 492 & $1 / 4$ & 183 \\
\hline Oct/D & 50 & 349 & $1 / 4$ & 146 & Oct/19 & 1 to 5 & 310 & $1 / 4$ & 231 \\
\hline Oct/D & 100 & 86 & 1 & 77 & Oct/21 & 1 to 5 & 306 & $1 / 4$ & 134 \\
\hline Oct/D & 150 & 234 & $1 / 2$ & 45 & Oct/23 & 1 to 5 & 298 & $1 / 4$ & 267 \\
\hline Oct/D & 200 & 206 & 1 & 6 & Oct/01 & 1 to 5 & 360 & $1 / 4$ & 344 \\
\hline Oct/N & 1 & 239 & $1 / 4$ & 449 & Oct/03 & 1 to 5 & 199 & $1 / 4$ & 436 \\
\hline Oct/N & 50 & 165 & $1 / 4$ & 69 & Oct/05 & 1 to 5 & 134 & $1 / 4$ & 350 \\
\hline Oct/N & 100 & 128 & $1 / 4$ & 104 & Oct/07 & 1 to 5 & 255 & $1 / 4$ & 114 \\
\hline Oct/N & 150 & 310 & $1 / 2$ & 15 & Oct/09 & 1 to 5 & 595 & $1 / 4$ & 30 \\
\hline Oct/N & 200 & 170 & 1 & 6 & Oct/11 & 1 to 5 & 74 & $1 / 4$ & 34 \\
\hline $\mathrm{Dec} / \mathrm{D}$ & 1 & 105 & $1 / 2$ & 78 & Oct/13 & 1 to 5 & 324 & $1 / 4$ & 68 \\
\hline $\mathrm{Dec} / \mathrm{D}$ & 50 & 241 & $1 / 2$ & 182 & Oct/15 & 1 to 5 & 327 & $1 / 4$ & 30 \\
\hline
\end{tabular}

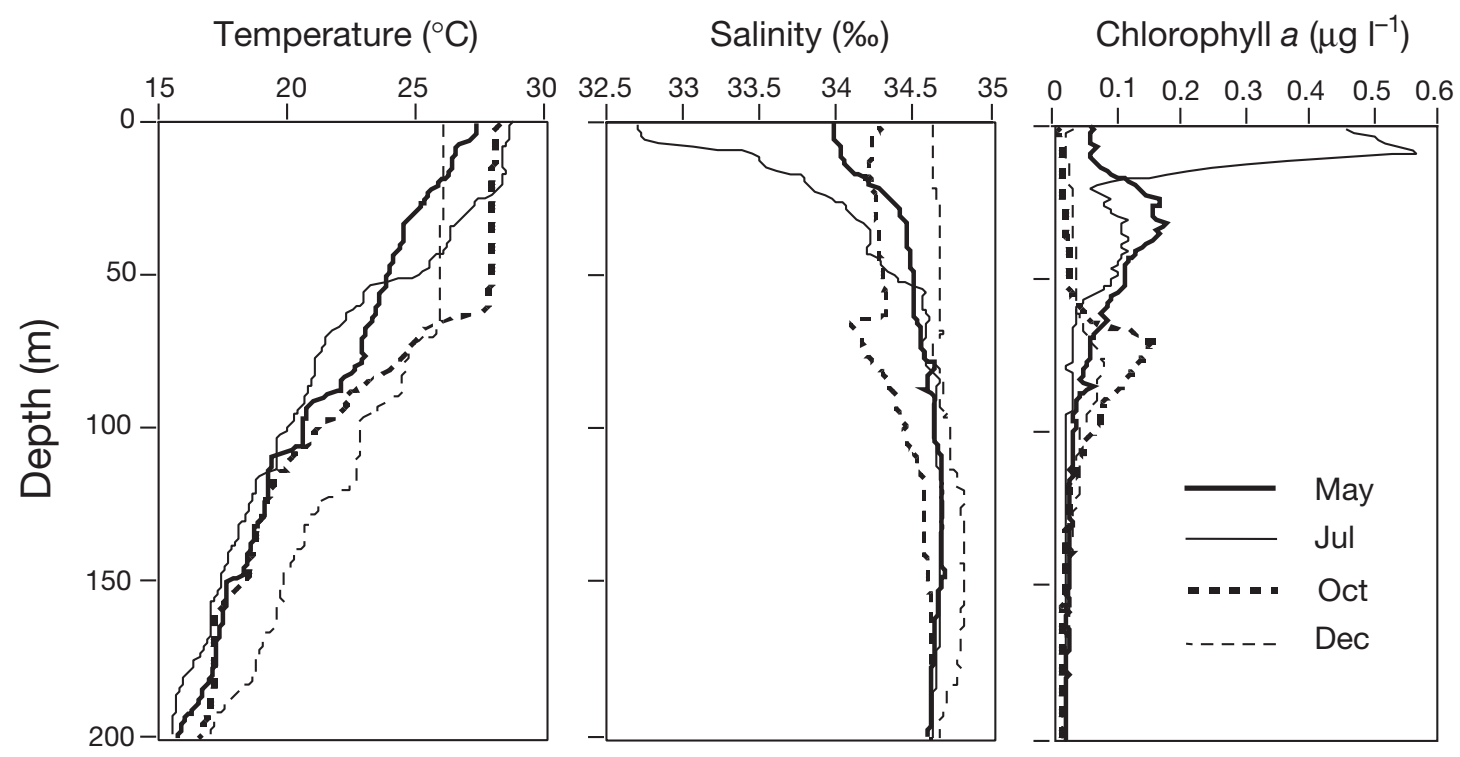

Fig. 2. Profiles of environmental parameters at station TS near Liuchiu island, southwestern Taiwan 
Table 2. The numerical abundance (mean $\pm \mathrm{SE}$ ), relative abundance $(\%)$ and night:day ratio (N:D) of thaliacean species for all samples (months and depths) found at Station TS near Liuchiu island in 1997. N, D: species was found only at night or during the day; +: relative abundance $<0.05 \%$; - : no data

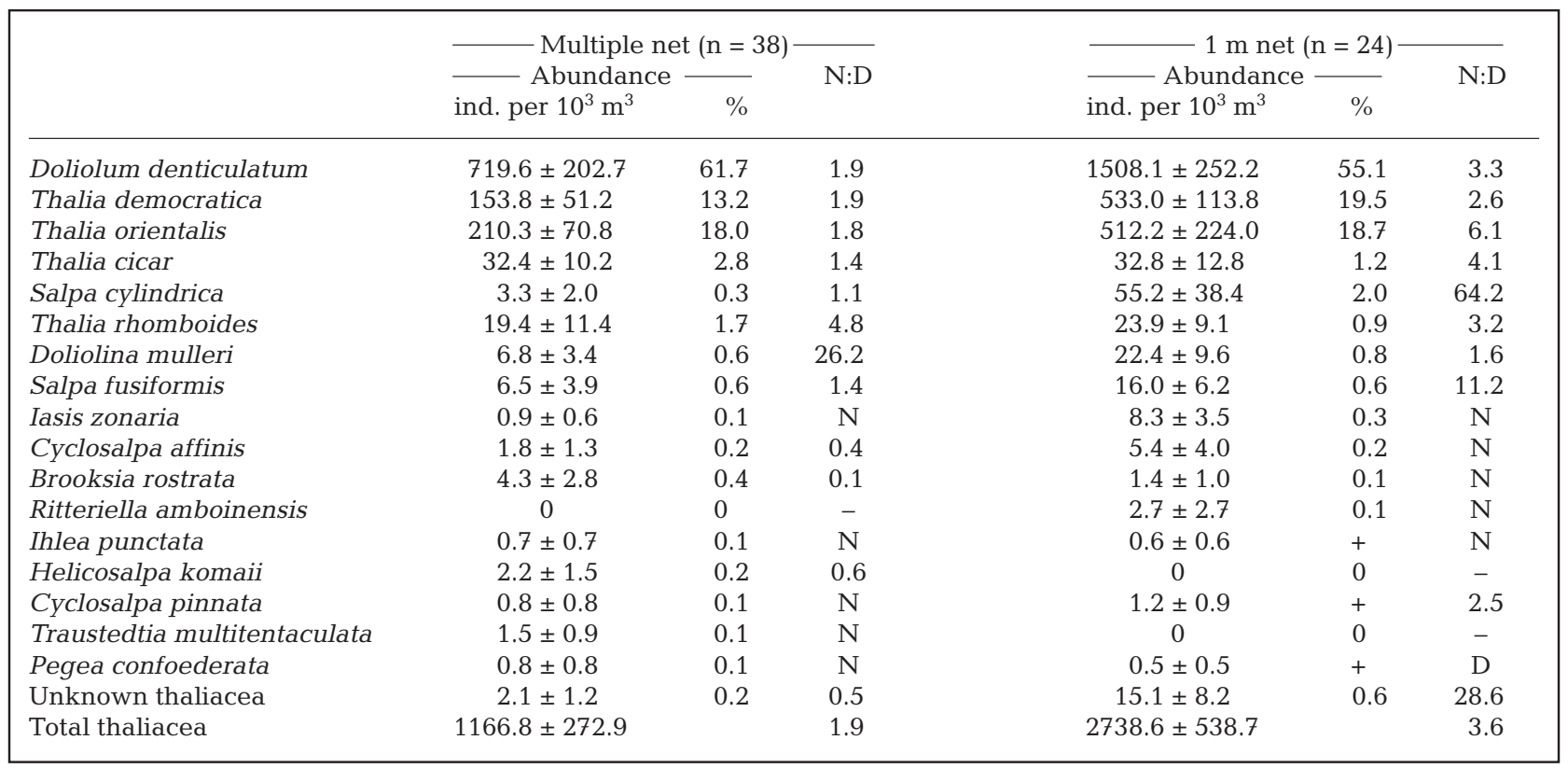
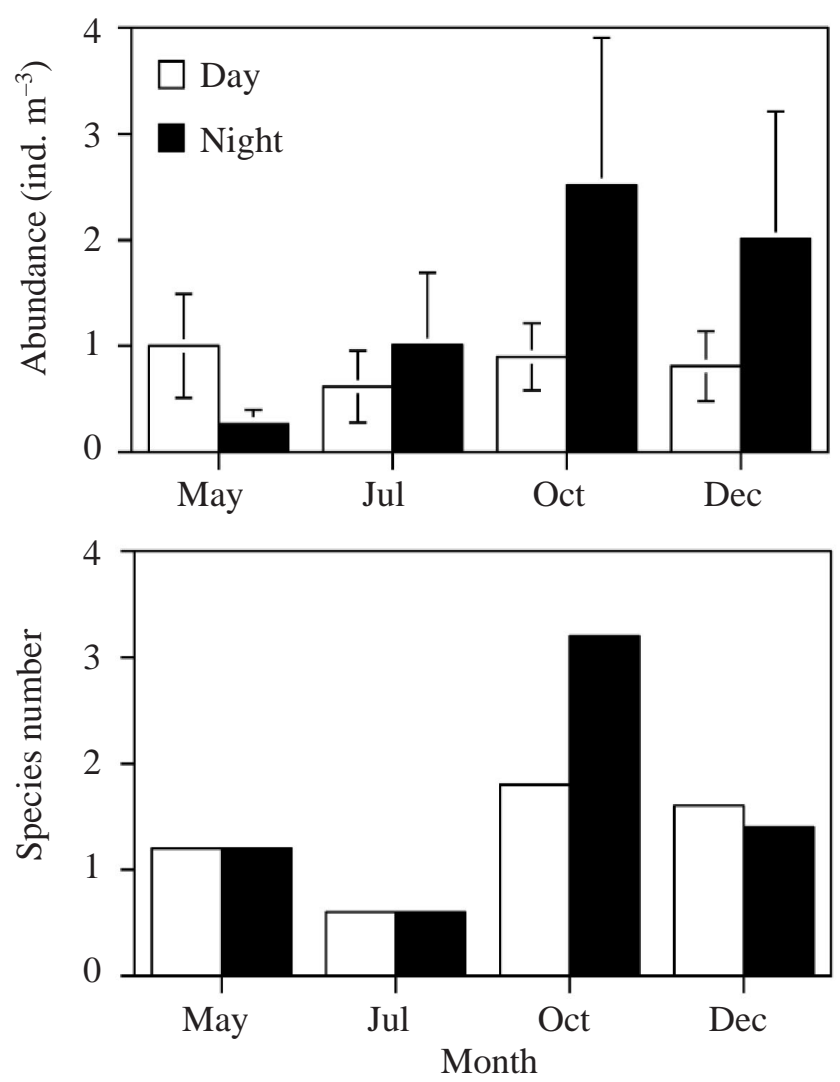

Fig. 3. Seasonal distribution in numerical abundance (mean \pm $\mathrm{SE}, \mathrm{n}=5$ ) and species number of thaliaceans collected by multiple net in the upper $200 \mathrm{~m}$ of the water column at station TS near Liuchiu island in 1997
Doliolum denticulatum was the most dominant species among the thaliaceans at this study site, with an average abundance of $0.7 \pm 0.2$ ind $\mathrm{m}^{-3}$, and comprised $62 \%$ of the total count of Thaliacea in the $200 \mathrm{~m}$ water column. It exhibited apparent seasonal change in abundance, with a peak abundance in October (>1 ind. $\mathrm{m}^{-3}$ ), and least abundance in May (Fig. 4). Different life stages of $D$. denticulatum showed different seasonal trends during the sampling periods. The phorozooid stage was the most abundant of all life stages. Its abundance increased from May to October but abruptly declined in December. The abundance of the oozooid stage increased in May, in the subsequent season, and became the most dominant stage (comprising $60 \%$ of the total count of this species) in December. The gonozooid stage was the least abundant of all life stages and generally contributed to less than $10 \%$ of the total number. Its abundance decreased from May to December. D. denticulatum was a typical epipelagic species that stayed mostly within the upper $50 \mathrm{~m}$ of the water column (Fig. 5). Its abundance was greater at night than during the day, with a night:day ratio of 1.9 when the data from the upper $200 \mathrm{~m}$ of the water column were integrated (Table 2). If different zooids were considered separately, it was apparent that phorozooids and gonozooids mainly inhabited the surface water, while most oozooids stayed at a depth of $50 \mathrm{~m}$ (Fig. 5).

Both solitary and aggregate zooids of Thalia democratica showed a clear seasonal change in abundance, 


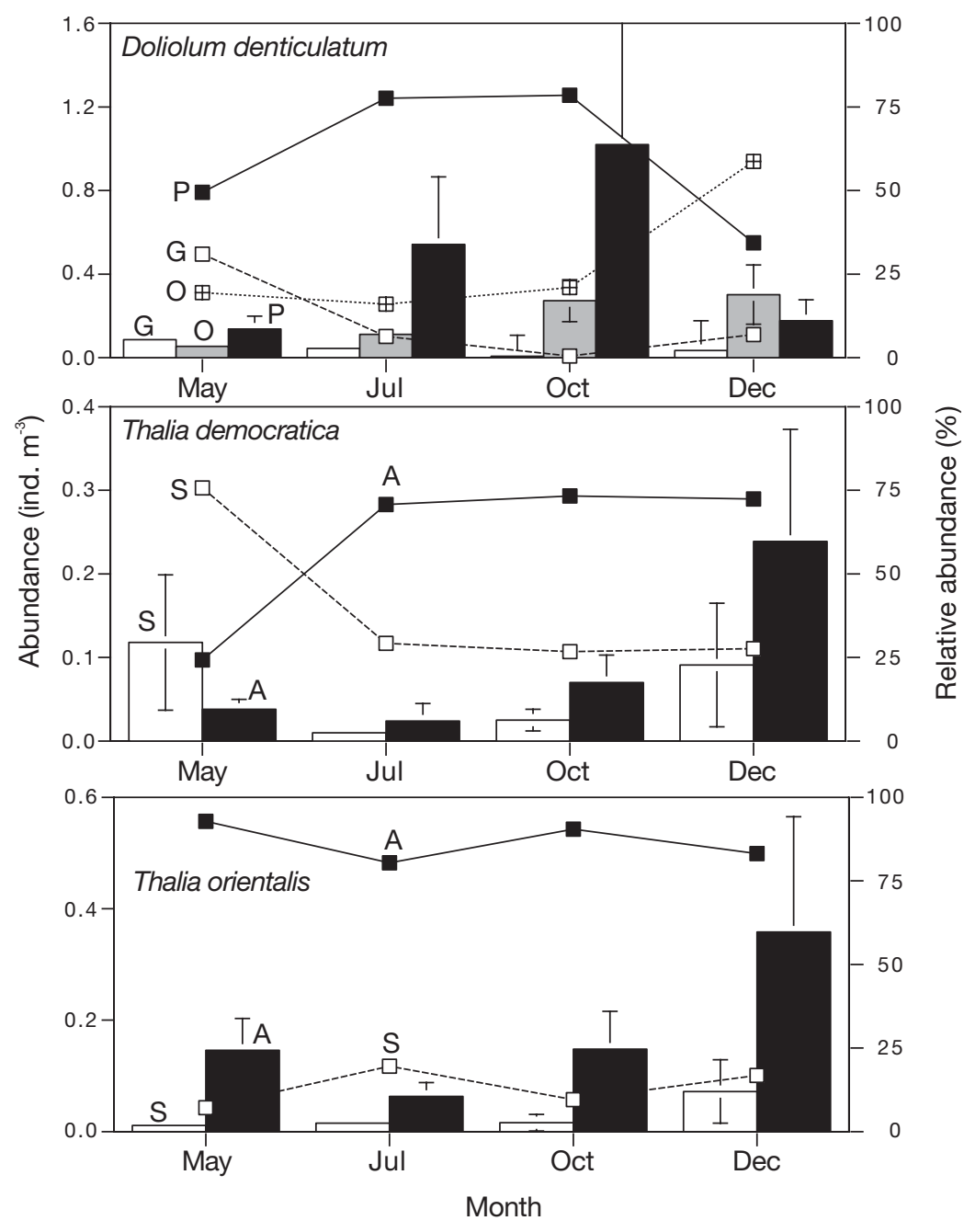

Fig. 4. Doliolum denticulatum, Thalia democratic and T. orientalis. Seasonal distribution in numerical abundance (mean $\pm \mathrm{SE}, \mathrm{n}=10$ ) collected by the multiple net in the upper $200 \mathrm{~m}$ of the water column at station TS near Liuchiu island in 1997. Bars and lines represent abundance and relative abundance, respectively. G: gonozooid; O: oozooid; $\mathrm{P}$ : phorozooid; S: solitary zooid; A: aggregate zooid

with the greatest abundance in December and the lowest abundance in July 1997 (Fig. 4). Solitary zooids comprised $76 \%$ of the total catch of the species in May, and about $27 \%$ in December. Aggregate zooids steadily increased from May to December, contrasting with the decline in solitary zooids over the same period. As far as numerical abundance is concerned, both solitary and aggregate zooids increased from July to December, aggregate zooids decreased from December to May, while solitary zooids increased over the same period. Furthermore, the night/day vertical distribution of $T$. democratica varied seasonally but the salps were mainly distributed in the upper $100 \mathrm{~m}$ of the water column, both during the day and at night (Fig. 6). The day/night vertical distribution of solitary and aggregate zooids showed different preferences for depths. Solitary zooids were mostly near surface water, particularly in May and December, while aggregate zooids were mainly at a depth of $50 \mathrm{~m}$ and had a higher abundance at night.

Thalia orientalis showed a similar seasonal distribution to that of $T$. democratica (Fig. 4), having a peak abundance in December, and lowest abundance in July. Aggregate zooids dominated in all samples, accounting for $>80 \%$ of the species in all seasons. Both zooids of this species were mainly found in the upper $100 \mathrm{~m}$ of the water column, and were relatively scarce at depths below $150 \mathrm{~m}$; however, solitary zooids were mainly found at depths between 50 and $100 \mathrm{~m}$, while aggregate zooids were found over the whole sampling depth (Fig. 7). Furthermore, this species showed seasonal differences in the night/day vertical distribution, with higher daytime abundance in May, no clear day/night difference in July, and peak nighttime abundance at depths of 100 and $50 \mathrm{~m}$ in October and December, respectively.

Based on the average weighted mean depths (WMD), the 3 most dominant thaliacean species seemed to stay at shallower depths at night, while remaining deeper in the water column during the day (Table 3). Both zooids of Thalia orientalis showed significant day/night differences (paired $t$-test, $\mathrm{p}<$ 0.05 ) in WMD, but no significant differences were found in the other 2 species. This confirms results that the majority of Doliolum denticulatum oozooids and solitary zooids of $T$. orientalis inhabit deeper water (59 to $104 \mathrm{~m})$, whereas gonozooids and phorozooids of $D$. denticulatum remain in shallower water (18 to $36 \mathrm{~m}$ ) (Table 3, Figs. 5 to 7 ). The night:day ratio of the 3 most dominant species, which averaged about 1.9, implied that the nighttime abundance of these species was about twice that of the day.

The abundance of the 3 dominant species was significantly correlated with the hydrological variables and varied with species and stages (Table 4). The abundances of Doliolum denticulatum gonozooids and Thalia democratica solitary zooids were negatively and significantly correlated with depth; the abundance of $D$. denticulatum oozooids, and aggregate zooids of 


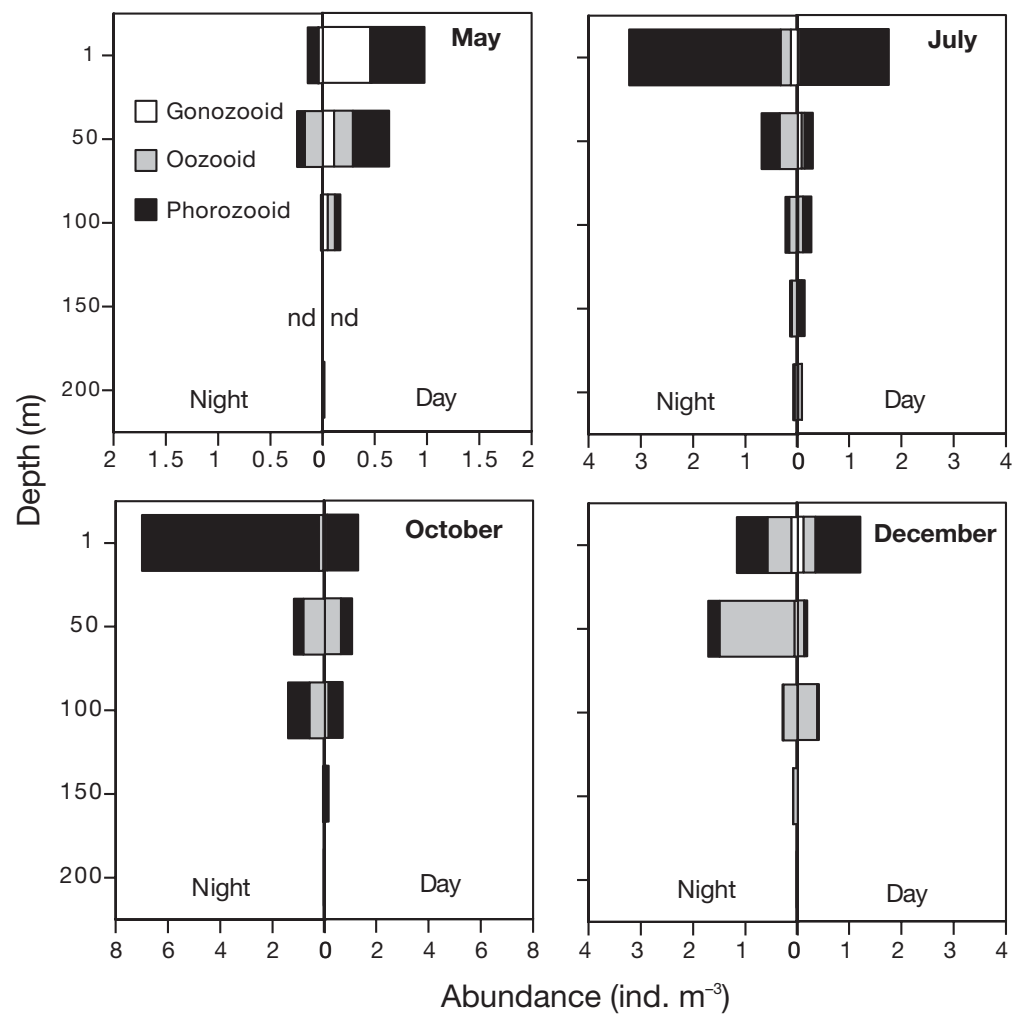

Fig. 5. Doliolum denticulatum. Seasonal change in night/day vertical distribution at station TS near Liuchiu island, southwestern Taiwan

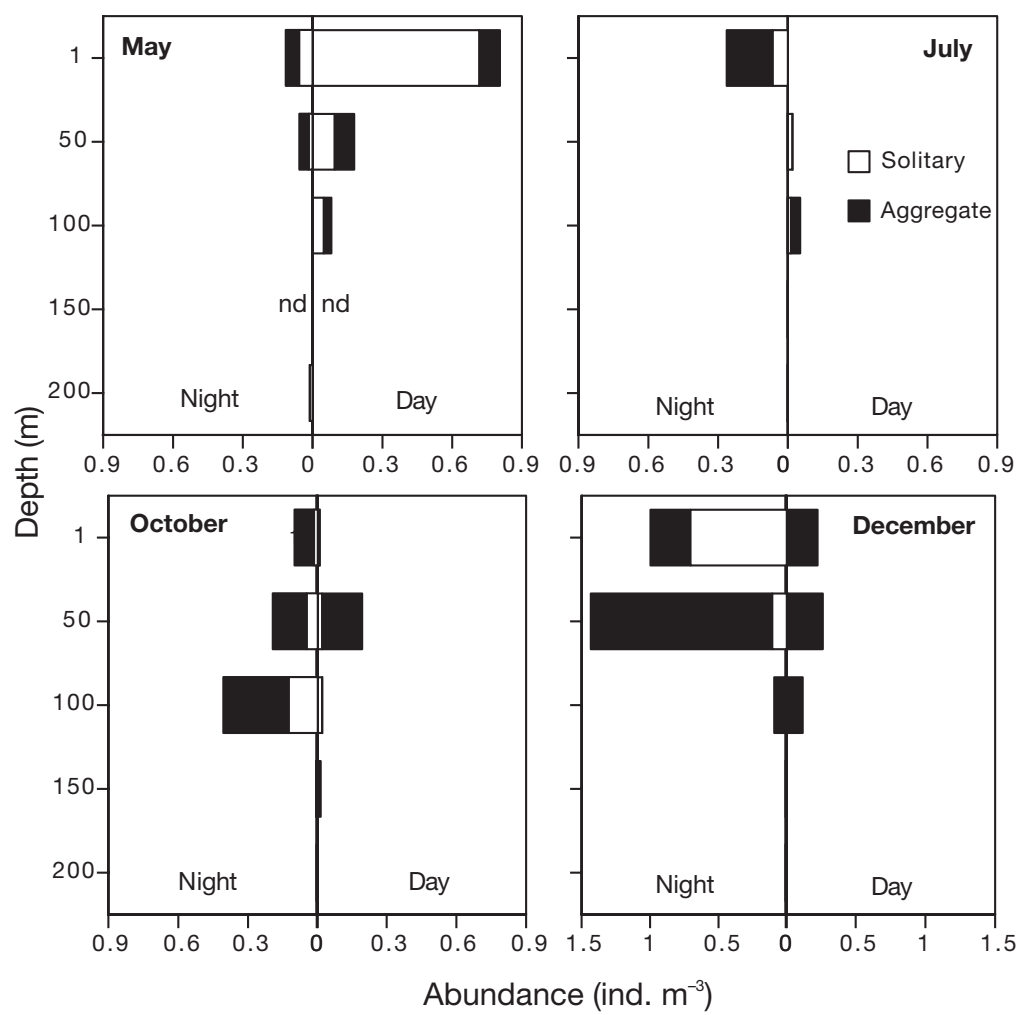

Fig. 6. Thalia democratica. Seasonal variation in night/day vertical distribution at station TS near Liuchiu island, southwestern Taiwan
T. democratica and $T$. orientalis were significantly influenced by temperature. The abundance of $D$. denticulatum oozooids and phorozooids showed significant correlation with salinity but with a reverse trend, while no significant relationship was found between thaliacean species and fluorescence.

\section{Time-series samplings within $24 \mathrm{~h}$}

Thirteen species of salps and 2 species of doliolids were identified in the $1 \mathrm{~m}$ net samples (Table 2). Doliolum denticulatum, Thalia democratica and $T$. orientalis were again the 3 most dominant species in both sampling seasons, and together contributed to $93 \%$ of the numerical total of Thaliacea. D. denticulatum was the most dominant species in both seasons, with an overall mean abundance of $1.5 \pm 0.3$ ind. $\mathrm{m}^{-3}$ and comprised $55.1 \%$ of total Thaliacea. T. democratica and T. orientalis ranked second and third, comprising 19.5 and $18.7 \%$, respectively. Local sunrise occurred at about 06:00 $\mathrm{h}$ and sunset at 18:00 $\mathrm{h}$ in both seasons; thus, we defined nighttime as 19:00 to 05:00 $\mathrm{h}$ and daytime as 07:00 to 17:00 h. We found nighttime abundances of the total thaliacean species to be 3 times more than daytime abundances when all the data were integrated.

In the $24 \mathrm{~h}$ time-series collections, 7 species of salps were found in March and 11 species in October 1997, plus 2 species of doliolids in both seasons (Table 2, Fig. 8). In March 1997, total thaliacean abundance steadily increased at night and reached a peak ( $\sim 7$ ind $\mathrm{m}^{-3}$ ) before midnight, and then decreased to $<1$ ind. $\mathrm{m}^{-3}$ near noon (11:00 h). Lowest abundance was found at 17:00 h. A similar trend was also found in species number (Fig. 8). However, the average abundance of total thaliacean species was not significantly different in terms of diel changes (Table 5). In October 1997, peak abundance was found close to dawn $(05: 00 \mathrm{~h})$ and the highest species number was found at 03:00 h. This was in contrast to the lowest values, which 


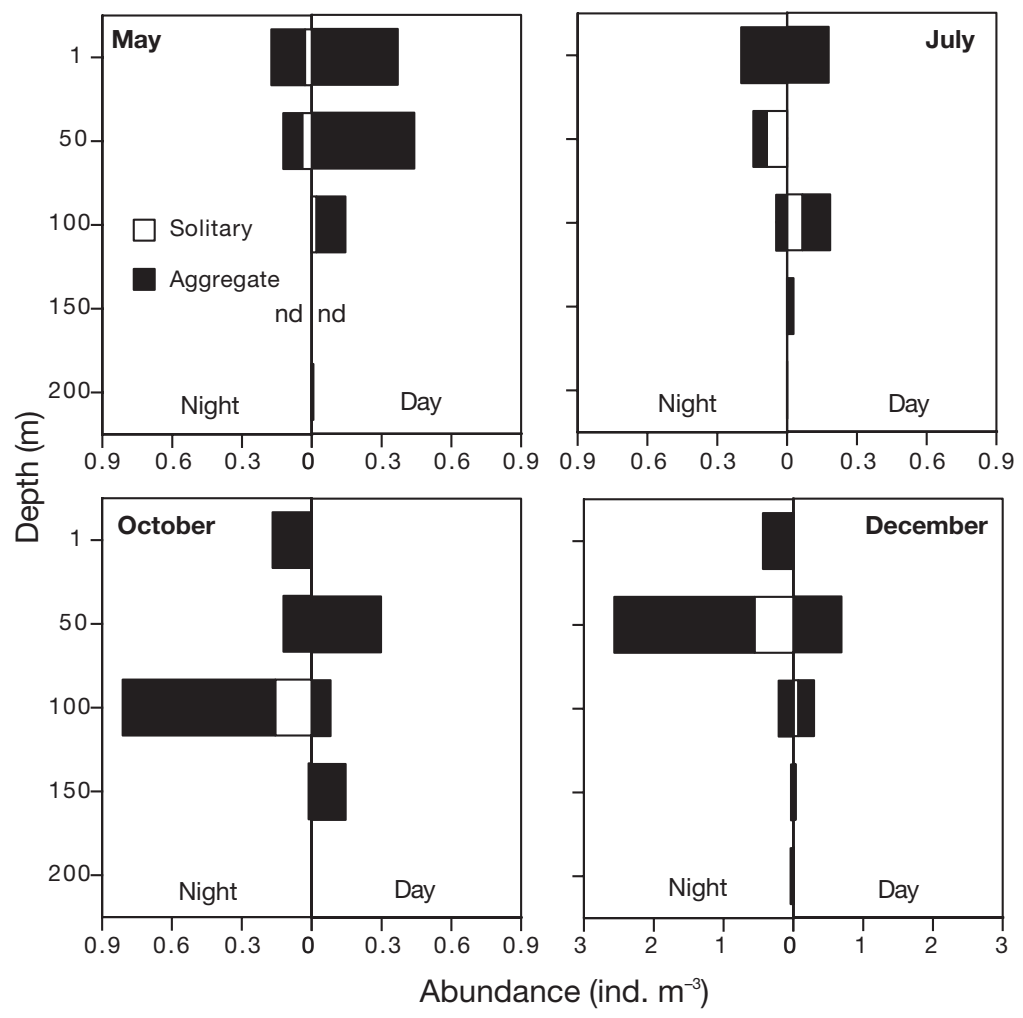

Fig. 7. Thalia orientalis. Seasonal variation in night/day vertical distribution at station TS near Liuchiu island, southwestern Taiwan
23:00 $\mathrm{h}$ in March, while in October it fluctuated throughout the diel period. The diel distribution patterns of $T$. orientalis and $T$. democratica were similar; they fluctuated in March and peaked at 05:00 and 03:00 $\mathrm{h}$, respectively in October. There was no significant difference $(p>0.05)$ in abundance between March and October in these dominant species. The abundance of total thaliaceans between day and night was significantly different in October but not in March. The abundance of $D$. denticulatum gonozooids and phorozooids in March was significantly different $(p<0.05)$ between day and night; phorozooid and oozooid stages in October showed significant changes in day/night abundance ( $\mathrm{p}<$ 0.05, Table 5). Except for the aggregate zooids of $T$. democratica in October, both solitary and aggregate generations of $T$. orientalis and T. democratica were generally not significantly different in abundance between day and night.
Table 3. Doliolum denticulatum, Thalia democratic and T. orientalis. Average weighted mean depths $(\mathrm{WMD}) \pm \mathrm{SE}$ for both day and night, and mean amplitude of the migration $(\mathrm{dm})$ at Station TS near Liuchiu island in 1997. ${ }^{* *},{ }^{*}$ : day and night differences (paired $t$-test) in WMDs are significant at the 0.01 and 0.05 levels, respectively. G: gonozooid; O: oozooid; P: phorozooid; S: solitary; A: aggregate

\begin{tabular}{|lcccc|}
\hline & & $\begin{array}{c}\text { WMD } \\
\text { (day) }\end{array}$ & $\begin{array}{c}\text { WMD } \\
\text { (night) }\end{array}$ & $\mathrm{dm}$ \\
\hline Doliolum denticulatum & $\mathrm{G}$ & $36 \pm 21$ & $23 \pm 8$ & 13 \\
& $\mathrm{O}$ & $78 \pm 14$ & $59 \pm 5$ & 19 \\
Thalia democratica & $\mathrm{P}$ & $24 \pm 8$ & $18 \pm 3$ & 6 \\
& $\mathrm{~S}$ & $53 \pm 14$ & $34 \pm 18$ & 19 \\
Thalia orientalis & $\mathrm{A}$ & $59 \pm 14$ & $34 \pm 15$ & 25 \\
& $\mathrm{~S}$ & $104 \pm 4$ & $59 \pm 15$ & $45^{* *}$ \\
& $\mathrm{~A}$ & $59 \pm 10$ & $43 \pm 13$ & $16^{*}$ \\
\hline
\end{tabular}

were observed at 09:00 h. Average nighttime abundance was significantly higher than during the day $(\mathrm{p}<$ 0.05), but species number showed no significant difference between night and day.

The diel period distribution patterns of the 3 most dominant thaliacean species, Diliolum denticulatum, Thalia orientalis and $T$. democratica showed that abundance was higher at night than during the day (Fig. 9). D. denticulatum was found to have a peak at
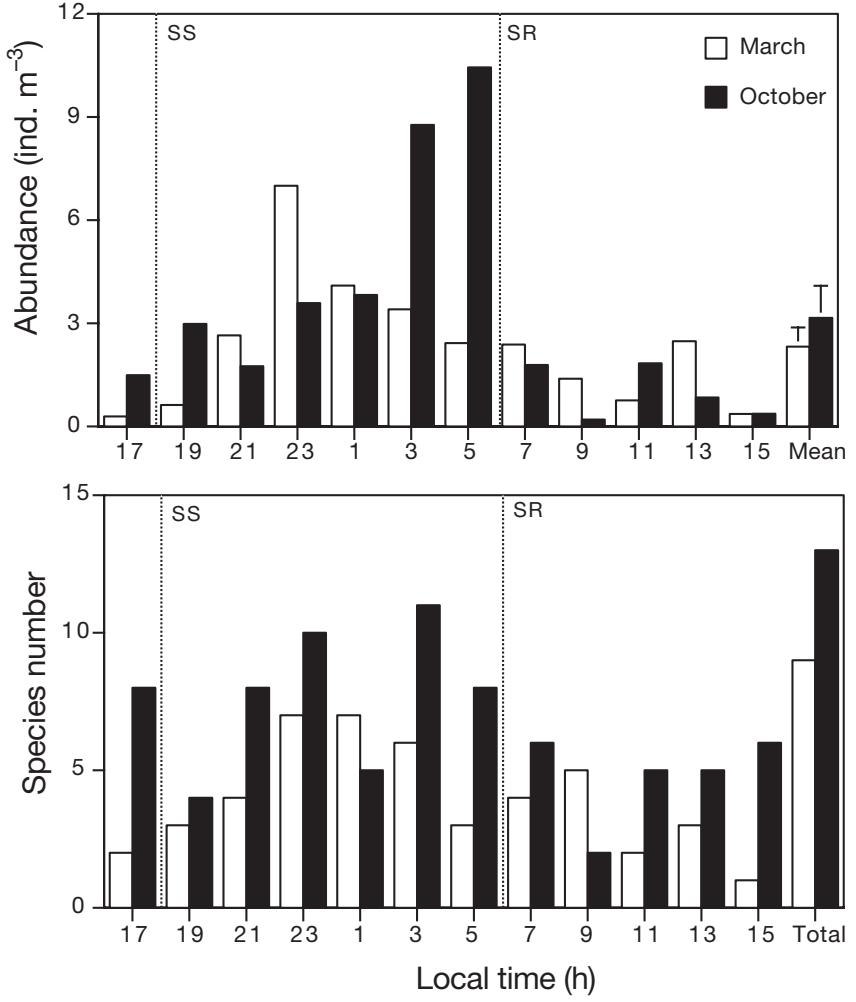

Fig. 8. Diel period distribution of abundance and species number of total thaliacean species in surface water at station

TS near Liuchiu island in 1997. SS: sunset; SR: sunrise 
Table 4. Doliolum denticulatum, Thalia democratic and T. orientalis. Results of forward stepwise regression and partial correlation coefficient (R) evaluating the relationships of the abundances of different life stages and environmental variables in multiple net samples. DDG: gonozooid of $D$. denticulatum; DDO: oozooid of $D$. denticulatum; DDP: phorozooid of $D$. denticulatum; TDS: solitary zooid of $T$. democratica; TDA: aggregate zooid of $T$. democratica; TOA: aggregate zooid of $T$. orientalis; D: depth; T: temperature; S: salinity; ns: not significant; ${ }^{*}: \mathrm{p}<0.05_{;}^{* *}: \mathrm{p}<0.001$

\begin{tabular}{|lccccl|}
\hline $\begin{array}{l}\text { Species } \\
\text { Life stages }\end{array}$ & $\begin{array}{c}\text { R for } \\
\text { depth }\end{array}$ & $\begin{array}{c}\text { R for } \\
\text { temperature }\end{array}$ & $\begin{array}{c}\text { R for } \\
\text { salinity }\end{array}$ & $\begin{array}{c}\text { R for } \\
\text { chlorophyll } a\end{array}$ & $\begin{array}{l}\text { Predictive } \\
\text { equation }\end{array}$ \\
\hline $\begin{array}{l}\text { Doliolum denticulatum } \\
\text { Gonozooid }\end{array}$ & $-0.480^{*}$ & -0.179 & -0.177 & 0.094 & DDG $=93.34-0.54 \mathrm{D}$ \\
$\quad \begin{array}{l}\text { Oozooid } \\
\text { Phorozooid }\end{array}$ & -0.240 & $0.642^{* *}$ & $0.354^{*}$ & 0.138 & $\begin{array}{l}\text { DDO }=-9795.60+41.45 \mathrm{~T}+263.29 \mathrm{~S} \\
\text { DDP }=61984.78-1784.97 \mathrm{~S}\end{array}$ \\
$\begin{array}{l}\text { Thalia democratica } \\
\text { Solitary zooid }\end{array}$ & -0.209 & $-0.573^{* *}$ & 0.285 & \\
$\quad$ Aggregate zooid & 0.089 & -0.097 & 0.080 & -0.090 & TDS $=143.37-0.87 \mathrm{D}$ \\
Thalia orientalis & $0.374^{*}$ & 0.248 & -0.044 & TDA $=-329.19+19.23 \mathrm{~T}$ \\
$\quad$ Solitary zooid & -0.133 & 0.173 & 0.107 & 0.002 & $\mathrm{~ns}$ \\
$\quad$ Aggregate zooid & 0.101 & $0.377^{*}$ & 0.240 & -0.066 & TOA $=-485.52+30.16 \mathrm{~T}$ \\
\hline
\end{tabular}

Table 5. Differences in abundance of the dominant thaliacean species between day $(07: 00$ to $17: 00 \mathrm{~h})$ and night $(19: 00$ to $05: 00 \mathrm{~h})$ using an unpaired $t$-test. ${ }^{*}: \mathrm{p}<0.05 i^{* *}: \mathrm{p}<0.01$

\begin{tabular}{|c|c|c|c|c|}
\hline & \multicolumn{2}{|c|}{$\longrightarrow$ March -} & \multicolumn{2}{|c|}{ October } \\
\hline & $t$-value & $\mathrm{p}$-value & $t$-value & $\mathrm{p}$-value \\
\hline Total thaliacean species & 2.192 & 0.054 & 2.831 & $0.018^{*}$ \\
\hline \multicolumn{5}{|l|}{ Doliolum denticulatum } \\
\hline Gonozooid & 2.622 & $0.025^{*}$ & 1.808 & 0.101 \\
\hline Phorozooid & 2.351 & $0.041^{*}$ & 3.224 & $0.009^{* *}$ \\
\hline Oozooid & 1.732 & 0.115 & 2.908 & $0.016^{*}$ \\
\hline \multicolumn{5}{|l|}{ Thalia democratica } \\
\hline Solitary zooid & 0.601 & 0.561 & 1.459 & 0.175 \\
\hline Aggregate zooid & 0.806 & 0.439 & 2.263 & $0.047^{*}$ \\
\hline \multicolumn{5}{|l|}{ Thalia orientalis } \\
\hline Solitary zooid & 1.474 & 0.172 & 1.983 & 0.076 \\
\hline Aggregate zooid & 0.306 & 0.766 & 1.914 & 0.085 \\
\hline
\end{tabular}

\section{DISCUSSION}

\section{Day-night vertical distribution and abundance}

Studies on Thaliacea in the western North Pacific Ocean are very sparse; only a few of studies have been published in China and Japan (He et al. 1988, Tsuda \& Nemoto 1992, Chen et al. 1994, Fu et al. 1995). The present study was the first to describe species composition and DVM of salps and doliolids in the surrounding water of Taiwan. It is difficult to compare our data with others, partly due to the difference in sampling strategies, and the scales of spatial and temporal variations. However, our results confirm previous studies that both Thalia democratica and Doliolum denticulatum are dominant and widely distributed in the western North Pacific Ocean and adjacent shelf waters. The abundance of Thaliacea in this study was similar to a previous study (Lo \& Hwang 2000) in the northern
South China Sea, and also to studies by Tsuda \& Nemoto (1992) and Fu et al. (1995) in waters adjacent to our study area. The abundance was, however, lower than in the studies reviewed by Deibel (1998) in other geographical areas.

The 3 most dominant thaliacean species, Thalia democratica, T. orientalis and Doliolum denticulatum in this study had higher abundances at night than during the day in the upper $200 \mathrm{~m}$ of the water column. They were mostly epipelagic and did not show clear DVM. Different life stages, however, might inhabit different layers of water within the upper $100 \mathrm{~m}$ and their abundance varied seasonally (Figs. 5 to 7 ). Gonozooids and phorozooids of $D$. denticulatum mainly lived in shallower water (18 to $36 \mathrm{~m}$ ), which was possibly food- and temperature-related (Gibson \& Paffenhöfer 2000); oozooids preferred to inhabit deeper water (59 to $78 \mathrm{~m}$ ), which coincided with lower chlorophyll a concentrations $\left(<0.1 \mu \mathrm{g} \mathrm{l}^{-1}\right)$. This might be a predator avoiding strategy (Ohman et al. 1983) or a strategy to conserve energy through a decrease in metabolic rate (Wiebe et al. 1979). The distribution patterns of $T$. democratica in this study agree with previous observations in the Agulhas Bank, where the species displays no vertical migration (Gibbons 1997), as well as in a Kuroshio warm-core ring, where both generations of this species dominate in the upper $20 \mathrm{~m}$ of the water column and show no DVM (Tsuda \& Nemoto 1992). T. democratica is thought to spawn when chains of aggregates are liberated from solitaries in early morning (Heron 1972). The shallower occurrence of the solitary zooids of $T$. demoncratica 


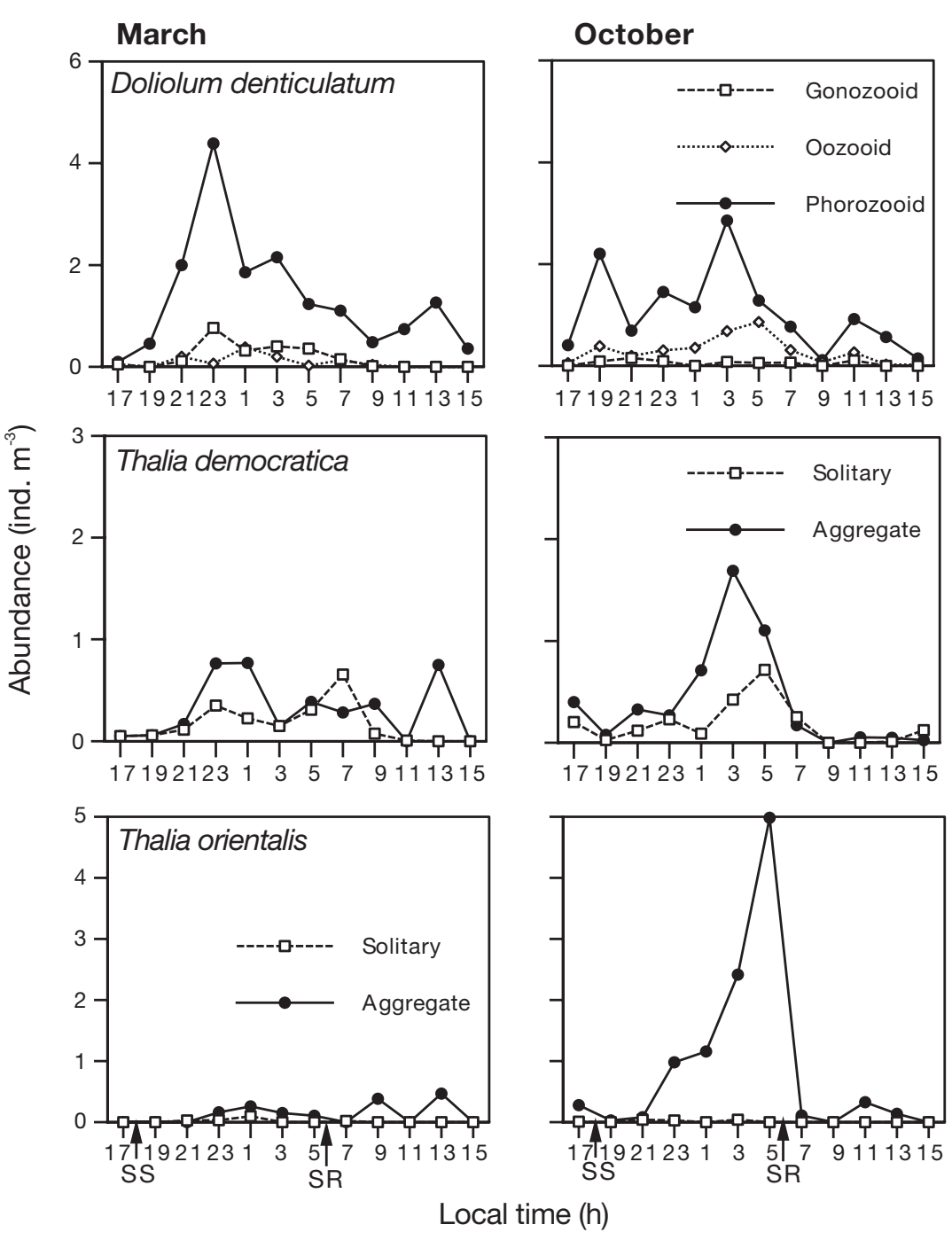

Fig. 9. Doliolum denticulatum, Thalia democratic and T. orientalis. Diel period distribution at station TS near Liuchiu island in 1997. SS: sunset; SR: surise

observed in the present study might be linked to sexual reproduction, similar to observations from the same species in Agulhas Bank (Gibbons 1997) and from Cyclosalpa bakeri in the subarctic Pacific (Purcell \& Madin 1991). T. orientalis has been rarely reported as a dominant species in other studies. Our data show that this species occurs throughout the upper $100 \mathrm{~m}$ of the water column and that its solitary zooids are less abundant and inhabit deeper water than aggregate zooids (Table 3, Fig. 7). According to Godeaux et al. (1998), Thalia generally has a very short generation time, in the order of days. The dominance of $T$. orientalis aggregate zooids in our samples was probably a result of random samplings during its asexual reproduction.

Doliolids are mostly epipelagic in the ocean (Paffenhöfer et al. 1995), and are found in or above the thermocline (Ménard et al. 1997). The distribution of
Doliolum denticulatum is limited by water temperature when it is less than $15^{\circ} \mathrm{C}$ (Berner \& Reid 1961), whereas in the present study the water temperatures above $200 \mathrm{~m}$ were higher than $15^{\circ} \mathrm{C}$ in all seasons; thus, temperature is not likely to be a limiting factor for this species in our study area. There was an indication from our samples that different stages of doliolids were located at different depths. Large proportions of gonozooids $(83 \%)$ and phorozooids $(89 \%)$ of D. denticulata were caught above the thermocline $(\sim 60 \mathrm{~m})$, and mainly in the surface water regardless of the season and time of day (Fig. 5). A similar result was reported by Paffenhöfer et al. (1995) for Dolioletta gegenbauri on the middle continental shelf off Georgia and South Carolina: namely, that more than $50 \%$ of the gonozooids assembled in the upper part of the water column. They found, however, that the oozooid stage of this species is more abundant $(51 \%)$ at around $50 \mathrm{~m}$ in all seasons and has an overall WMD of $71 \mathrm{~m}$ during the day and $59 \mathrm{~m}$ at night.

The high abundance and species richness in October in multiple-net collections (Fig. 3) suggested that autumn, at the end of the wet season and during the transition period between southwest and northeast monsoons, might be a more favorable season for most thaliacean species to live and reproduce in this region. However, Ménard et al. (1994) found that Thalia democratica and Salpa fusiformis were more abundant from April to June in the Mediterranean Sea, and proposed that this might be a result of the spring phytoplankton bloom. Ménard et al. (1997) reported that doliolids in the bay of the northwestern Mediterranean Sea were abundant mostly from July to December and seemed to be temperature-related, while Gibson \& Paffenhöfer (2000) further revealed that the feeding and growth rates of doliolids are a function of food concentration and temperature. Our results show that there are more thaliaceans, particularly Doliolum denticulatum in October, and their abundance is likely affected by temperature and salinity in this study area (Table 4).

Two dominant thaliaceans, Thalia democratica and Doliolum denticulatum, displayed alternation of asexual-sexual reproduction in different seasons in this study. In T. democratica, a solitary-dominated popula- 
tion $(80 \%)$ in late spring was replaced by an aggregate-dominated population in autumn (75\%) and winter (80\%) (Fig. 4). Heron \& Benham (1985) studied the growth rate of salps in the Indo-West Pacific near Australia and found that juvenile solitary and mature aggregates of $T$. democratica were absent in winter, probably due to unfavorable conditions (i.e. stronger monsoon and lack of food), while an increase in mature solitary and young aggregates in spring and summer suggested more favorable conditions (i.e. phytoplankton blooming and warmer water temperatures) for thaliaceans to grow. In their samples, aggregate zooids were more abundant than solitary zooids in all seasons. Further studies are needed to examine whether this change was simply a result of random sampling or whether it was due to other hydrological effects. The phorozooid stage of $D$. denticulatum was by far the most common life stage $(\sim 80 \%)$ in summer and autumn, suggesting that asexual reproduction prevailed during these seasons. Oozooids were found in larger proportions ( $55 \%)$ in winter, indicating that it was possibly a suitable season for sexual reproduction of this species. Similar results were recorded by Braconnot (1963) (cited in Deibel 1998) in the Mediterranean, Russell \& Colman (1935) (cited in Deibel 1998) in the waters surrounding the Great Barrier Reef, and Paffenhöfer et al. (1995) off the southeastern USA during winter.

\section{Time-series observations}

As far as we know, few studies in the literature address the diel time scale of the migration of Thaliacea. Atkinson et al. (1978) documented the abundance of doliolids increasing from 7 to 10 -fold between midnight (minimum) and noon (maximum) at a station off Augustine, Florida, with 3 to $12 \mathrm{~h}$ time-interval samplings in 3 consecutive days. However, their results did not discuss the species or stage levels and the mechanism of this diel variability. Andersen et al. (1992) noted that Pyrosoma atlanticum showed a clear diurnal symmetry from a time-series of horizontal hauls around sunrise (02:00 to 08:00 h) and sunset (15:00 to $20: 00 \mathrm{~h})$ at a depth of $230 \mathrm{~m}$ in the NW Mediterranean Sea. The bulk of the population crosses this depth before sunrise during its descent and after sunset during its upward migration. From our observations of $24 \mathrm{~h}$ time series samplings, most stages or generations of these 3 thaliacean species showed higher abundance at night, but their peak abundance occurred at different times between 23:00 and 05:00 h, and varied seasonally. We speculate that these thaliaceans are epipelagic species that migrate vertically within a small range to and from the surface on a diel basis. It is further evident from our results of multiplenet samples that most of these thaliaceans have shallow WMDs both during the day and at night. The potential metabolic advantage could be important for a species such as Salpa aspera, which migrated through a depth of $800 \mathrm{~m}$ with a temperature gradient of over $20^{\circ} \mathrm{C}$ (Wiebe et al. 1979). Metabolic advantages for the species reported in this study, which migrates through a temperature range of less than $5^{\circ} \mathrm{C}$, if present at all, would be minimal. Some salmonids, clupeids and anchovies, which are known to prey on salps, might affect the DVM pattern of salps (Kashkina 1986, Harbison 1998, Mianzan et al. 2001). However, we did not have information on any predator in our study area and were, therefore, unable to assess potential predation pressures on the behavior of salps. We cannot eliminate the possibility of predator-caused descent of salps and doliolids during the daytime in this area.

In conclusion, the 3 dominant thaliacean species, Doliolum denticulatum, Thalia democratica and T. orientalis, were typically epipelagic in this study site. They mostly stayed in the upper $100 \mathrm{~m}$ of the water column, both during the day and at night, throughout the year. Different life stages of these species tended to stay at different depths of the water column, but most of them showed no clear DVM despite their abundances at night being usually higher than during the day. Most thaliacean species in this study showed seasonal changes in abundance, and perhaps alternation of generation during the year. We speculate, based on the low thaliacean abundance and chlorophyll a concentration in this study area, that these distribution patterns might be food-limited and reproductionrelated. Furthermore, significant correlations between thaliacean abundance and water temperature and salinity could have been influenced by hydrographic conditions (i.e. alternate intrusions of the Kuroshio Branch Current and South China Sea Warm Waters) and southwest and northeast monsoons.

Acknowledgements. We thank the crew of the RV 'Ocean Research III' for their assistance in collecting zooplankton samples and other environmental data. We are grateful to Dr. C.-t. Shih for critical review of and valuable comments on the manuscript. We also acknowledge comments on an earlier version of the manuscript from Dr. G. A. Paffenhöffer and 2 anonymous reviewers. This research was supported by a grant from the National Science Council of the Republic of China to W.T.L. (NSC90-2621-Z 110-008).

\section{LITERATURE CITED}

Andersen V, Sardou J (1994) Pyrosoma atlanticum (Tunicata, Thaliacea): diel migration and vertical distribution as a function of colony size. J Plankton Res 16:337-349

Andersen V, Sardou J, Nival P (1992) The diel migration and vertical distribution of zooplankton and micronekton in 
the Northwestern Mediterranean Sea. 2. Siphonophores, hydromedusae and Pyrosomids. J Plankton Res 14(8): 1155-1169

Atkinson LP, Paffenhöfer GA, Dunstan WM (1978) The chemical and biological effect of a Gulf Stream intrusion off St. Augustine, Florida. Bull Mar Sci 28:667-679

Bathmann UV (1988) Mass occurrence of Salpa fusiformis in the spring of 1984 off Ireland: Implications for sedimentation process. Mar Biol 97:127-135

Berner LD, Reid JLJr (1961) On the response to changing temperature of the temperature-limited plankter Doliolum denticulatum Quoy and Gaimard 1835. Limnol Oceanogr 6:205-215

Braconnot JC (1963) Étude du cycleannuel des Salpes et Dolioles en rade de Villefranche-sur-Mer. J Cons Int Exp Mer 28:21-36

Chen QC, Huang LM, Yin JQ, Zhang GX (1994) Studies on the zooplanktonic biodiversities in the waters around Nansha Islands. In: Juang IC (ed) Studies on marine biodiversities of the Nansha Islands and neighboring waters I. China Ocean Press, Beijing, p 42-50

Chihara M, Murano M (1997) An illustrated guide to marine plankton in Japan. Tokai University Press, Tokyo, p 1357-1392

Deibel D (1998) The abundance, distribution, and ecological impact of doliolids. In: Bone Q (ed) The biology of pelagic tunicates. Oxford University Press, Oxford, p 171-186

Enright JT (1977) Diurnal vertical migration: adaptive significance and timing. Part 1. Selective advantage: a metabolic model. Limnol Oceanogr 22:856-872

Fong SC, Ting YY, Lu HS, Chow SC (1990) Tagging experiment on the grass prawn, Penaeus monodon in southwestern coast of Taiwan. Bull Inst Zool Acad Sinica 29(2):71-80

Fu YY, Yin JQ, Chen QC, Huang LM, Wong CK (1995) Distribution and seasonality of marine zooplankton in the Pearl River estuary. In: Wong CK, Chu KH, Chen QC, Ma XL (eds). Environmental research in Pearl River and coastal areas. Guandong Higher Education Press, Guanzhou, p 25-33

Gibbons MJ (1997) Vertical distribution and feeding of Thalia democratica on the Agulhas Bank during March 1994. J Mar Biol Assoc UK 77:493-505

Gibson DM, Paffenhöfer GA (2000) Feeding and growth rates of the doliolid, Dolioletta gegenbauri Uljanin (Tunicata, Thaliacea). J Plankton Res 22:1485-1500

Godeaux J (1998) The relationships and systematics of the Thaliacea, with keys for identification. In: Bone Q (ed) The biology of pelagic tunicates. Oxford University Press, Oxford, p 273-294

Godeaux J, Bone Q, Braconnot JC (1998) Anatomy of Thaliacea. In: Bone Q (ed) The biology of pelagic tunicates. Oxford University press, Oxford, p 2-24

Gorsky G, Lins da Silva N, Dallot S, Laval P, Braconnot JC, Prieur L (1991) Midwater tunicates: are they related to the permanent front of the Ligurian Sea (NW Mediterranean)? Mar Ecol Prog Ser 74:195-204

Haney JF (1988) Diel patterns of zooplankton behaviour. B Mar Sci 43:583-603

Harbison GR (1998) The parasites and predators of Thaliacea. In: Bone Q (ed) The biology of pelagic tunicates. Oxford University Press, Oxford, p 187-214

He D, Yang G, Fang S, Shen W, Liu H, Gao A, Huang S (1988) Study of zooplankton ecology in Zhejiang coastal upwelling system- zooplankton biomass and abundance of major groups. Acta Oceanol Sin 7:607-620

Heron AC (1972) Population ecology of a colonizing species: the pelagic tunicate Thalia democratica. I. Individual growth rate and generation time. Oecologia 10:269-293

Heron AC, Benham EE (1985) Life history parameters as indicators of growth rate in three salp populations. J Plankton Res 7:365-379

Hung JJ, Shy CP (1995) Speciation of dissolved Se in the Kaoping and Erhjen rivers and estuaries, southwestern Taiwan. Estuaries 18:234-240

Huntley ME, Skyes PF, Marin V (1989) Biometry and triphodynamics of Salpa thompsoni foxton (Tunicata: Thaliacea) near the Antarctic Peninsula in austral summer, 19831984. Polar Biol 10:59-70

Hwang JJ, Lo WT (2002) The coupling of tintinnid ciliate community and hydrography in the coastal waters southwest of Taiwan. J Fish Soc Taiwan 29(4):334-342

Kashkina AA (1986) Feeding of fishes on salps (Tunicata, Thaliacea). J Icthyol 26:57-64

Li L, Su J, Xu JP (1997) Detached Kuroshio rings in the South China Sea. Tropic Oceanol 16:42-57

Lo WT, Hwang JS (2000) The diel vertical distribution of zooplankton in the northern South China Sea. Natl Taiwan Mus Spec Publ Ser 10:59-73

Lo WT, Hwang JS, Chen QC (2001) Identity and abundance of surface-dwelling, coastal copepods of southwestern Taiwan. Crustaceana 74:1139-1157

Lo WT, Chung CL, Shih CT (2004) Seasonal variations of copepods in the Tapong Bay southwest of Taiwan. Zool Stud 43:218-228

Madin LP, Kremer P, Hacker S (1996) Distribution and vertical migration of salps (Tunicata, Thaliacea) near Bermuda. J Plankton Res 18:747-755

Ménard F, Dallot S, Thomas G, Braconnot JC (1994) Temporal fluctuations of two Mediterranean salp populations from 1967 to 1990. Analysis of the influence of environmental variables using a Markov chain model. Mar Ecol Prog Ser 104:139-152

Ménard F, Fromentin JM, Goy J, Dallot S (1997) Temporal fluctuations of doliolid abundance in the bay of Villefranche-sur-Mer (northwestern Mediterranean Sea) from 1967 to 1990. Oceanol Acta 20:733-742

Mianzan H, Pájaro M, Alvarez Colombo G, Madirolas A (2001) Feeding on survival-food: gelatinous plankton as a source of food for anchovies. Hydrobiologia 451:45-53

Mok HK, Kuo CH (2001) Myxine formposana, a new species of hagfish (Myxiniformes:Myxinidae) from the southwestern waters of Taiwan. Ichthyol Res 48:295-297

Ohman MD, Frost BW, Cohen EB (1983) Reverse diel vertical migration: an escape from invertebrate predators. Science 220:1404-1407

Paffenhöfer GA, Atkinson LP, Lee TN, Verity PG, Bulluck LRIII (1995) Distribution and abundance of thaliaceans and copepods off the southern U.S.A during winter. Cont Shelf Res 15:255-280

Pearre S Jr (1973) Vertical migration and feeding in Sagitta elegans Verrill. Ecology 54:300-314

Purcell JE, Madin LP (1991) Diel patterns of migration, feeding, and spawning by salps in the subarctic Pacific. Mar Ecol Prog Ser 73:211-217

Roe HSJ, Angel MV, Badcock J, Domanski P, James PT, Pugh PR, Thurston MH (1984) The diel migrations and distributions within a mesopelagic community in the northeast Atlantic. I. Introduction and sampling procedures. Prog Oceanogr 13:245-268

Russell FS, Colman JS (1935) The zooplankton IV. The occurrence and seasonal distribution of the Tunicata, Mollusca and Coelenterata (Siphonophora). Sci Rep Great Bar Reef Exp 2:205-234

Shaw PT (1989) The intrusion of water masses into the sea 
southwest of Taiwan. J Geophys Res 94:18213-18226

Shaw PT (1992) Shelf circulation off the southeast coast of China. Rev Aquat Sci 6:1-28

Soong K, Chen JL (1991) Population structure and sex change of coral-inhabiting snail, Coralliophila violacea, at HsiaoLiuchiu, Taiwan. Mar Biol 106:81-86

Thompson H (1948) Pelagic tunicates of Australia. Commonwealth Council for Scientific and Industrial Research, Melbourne

Tseng RS (2002) On the dispersion and diffusion near estuaries and around islands. Estuar Coast Shelf Sci 54:89-100

Tsuda A, Nemoto T (1992) Distribution and growth of salps in a Kuroshio warm-core ring during summer 1987. DeepSea Res 39(1):219-229

Wang J, Chern CS (1987) The warm-core eddy in the northern

Editorial responsibility: Jennifer Purcell (Contributing Editor), Anacortes, Washington, USA
South China Sea. Acta Oceanogr Taiwanica 18:92-113

Wiebe PH, Madin LP, Haury LR, Harbison GR, Philbin LM (1979) Diel vertical migration by Salpa aspera and its potential for large-scale particulate organic matter transport to the deep-sea. Mar Biol 53:249-255

Xu JP, Su JP (1997) Hydrographic analysis on the intrusion of the Kuroshio into the South China Sea. II. Observational results during the cruise from August to September in 1994. Tropic Oceanol 16:1-23

Yount JL (1954) The taxonomy of the Salpidae (Tunicata) of the central Pacific Ocean. Pac Sci 8:276-330

Zeldis JR, Davis CS, James MR, Ballara SL, Booth WE, Chang FH (1995) Salp grazing: effects on phytoplankton abundance, vertical distribution and taxonomic composition in a coastal habitat. Mar Ecol Prog Ser 126:267-283

Submitted: May 10, 2004; Accepted: December 8, 2004 Proofs received from author(s): April 23, 2005 